\title{
Saving the Whales: Lessons from the Extinction of the Eastern Arctic Bowhead
}

\author{
RoBert C. AlLEN AND IAN KEAY
}

In this article we investigate the possibility that a regulatory regime designed to maximize the profitability of the early Dutch whaling industry could have simultaneously guaranteed the biological sustainability of the eastern Arctic Bowhead whale. We find that policies with economic profit as the sole objective could have saved the whales, as well as increasing the incomes of the whalers, under assumptions commonly made in fisheries models. However, the necessary assumptions are implausible. Under more historically relevant assumptions we find that regulation could not have simultaneously increased profits and preserved the stock of whales.

E conomic expansion poses many environmental challenges including the survival of species. Biologists and economists have developed models to explore this issue. However, it is a question for which the study of history can make contributions beyond the reach of other disciplines. A historical approach emphasizes the importance of contingent events that are often overlooked in standard analysis. These include international rivalry, war, climate change, and, more generally, the reassessment of policy in the light of changing circumstances. We explore these issues, particularly the implications of policy reassessment, using the commercial exploitation of the eastern Arctic Bowhead whale (Balaena Mysticetus) as a case study.

When the first European explorers ventured into the eastern Arctic Ocean during the early years of the seventeenth century, they remarked on the profusion of Bowhead whales and their economic potential. "The killing of the whale is both pleasant and profitable, and without great charges, yielding great plenty of oil, the tun whereof is worth ten pounds." Very soon after European discovery the Dutch, relying al-

The Journal of Economic History, Vol. 64, No. 2 (June 2004). (C) The Economic History Association. All rights reserved. ISSN 0022-0507.

Robert C. Allen, is Professor, Nuffield College, Oxford University, Oxford, United Kingdom, OX1 1NF. E-mail: bob.allen@nuffield.oxford.ac.uk. Ian Keay is Assistant Professor, Department of Economics and School of Environmental Studies, Queen's University, Kingston, Ontario, Canada, K7L 3N6. E-mail: ikeay@qed.econ.queensu.ca.

The authors would like to thank seminar participants at Carleton University, Queen's University, University of California - Los Angeles, California Institute of Technology, Oxford University, the University of Colorado (Boulder), the 2002 C.E.A. meetings in Calgary, Alberta, and the 2002 E.H.A. meetings in St. Louis, Missouri. The authors gratefully acknowledge the funding provided by S.S.H.R.C. (Grant \# 410-2002-1293) for this project. All remaining errors and omissions are the responsibility of the authors

${ }^{1}$ Quoted by Jackson, British Whaling, p. 5. 
most exclusively on the Greenland-Spitzbergen and Davis Strait stocks of Bowhead whales, established the largest commercial whaling industry in Europe. ${ }^{2}$ During the period of Dutch dominance, from the midseventeenth until the mid-eighteenth century, there were no regulations constraining the number of vessels participating in the hunt. Indeed, rather than attempting to restrict participation, the Dutch government sought to foster effort expansion. ${ }^{3}$ The objective of these government policies was the promotion of whaling as a means of training sailors for the Dutch Navy.

The British government was favorably impressed by the quality and quantity of sailors the Dutch Navy was able to acquire from their domestic whaling fleet. Anxious to emulate this success, during the mideighteenth century the British government provided direct subsidies to captains willing to participate in the eastern Arctic whale hunt. The subsequent British competition, in conjunction with Dutch military and naval entanglements in Europe, drove the Dutch out of the business. The unfettered British whalers then hunted the Greenland-Spitzbergen and Davis Strait Bowhead stocks to the brink of extinction in the early nineteenth century. Today there is no identifiable Greenland-Spitzbergen stock of Bowhead whales, and only a small number of individuals remain in the Davis Strait stock. ${ }^{4}$

In this article we probe an issue of considerable interest to economic historians: the relationship between property rights and social performance. Whaling during the era of Dutch dominance was an "open access fishery." Was the extinction of the Bowhead whale, therefore, an example of the "tragedy of the commons"? Could regulation designed to solve the problem of open access have saved the whales? We show that the issue is complex. Although regulation was a necessary condition for saving the whales, it was not sufficient. Regulations designed to prevent excess entry and rent dissipation would have saved the whales under the static and ahistorical assumptions typically made in the resource management literature. These assumptions include the single regulatory objective of profit maximization, perfect foresight into the indefinite future, and the indefinite maintenance of a regulatory regime once it is put in place - policy updating, in other words, is precluded. However, when other objectives such as the maintenance of employment are allowed or when policy is revised in the light of new information, the stock of

\footnotetext{
${ }^{2}$ During the seventeenth century there were five geographically distinct stocks of Bowhead whales; the Greenland-Spitzbergen stock, the Davis Strait stock, the Hudson Bay stock, the western Arctic stock, and the Sea of Okhotsk stock. See Braham, "Bowhead Whale."

${ }^{3}$ de Vries and van der Oude, First Modern Economy, pp. 264-65.

${ }^{4}$ Vibe, “Arctic Animals," pp. 81-82; and de Jong, "Hunt of the Greenland Whales," p. 90.
} 
whales once again begins to decline. The trend toward extinction is less rapid than under open-access conditions, but it is inexorable even when the industry is regulated.

We reach these conclusions by using a simulation model of the whaling industry. The model has much in common with standard resource models: The representation of whale biology is orthodox as are the characterization of whaling "effort" (the number whaling ships and the effectiveness of their search) and the demand for whale oil and baleen. However, our model imposes fewer a priori equilibrium assumptions and more readily admits contingent factors and policy reassessment. A flexible model such as this is important to integrate the ecological approach with historical understanding.

\section{RENEWABLE RESOURCE THEORY AND THE TRAGEDY OF THE COMMONS}

Early pelagic whaling was an "open access fishery," which implies that there were no regulations restricting participation. H. S. Gordon illustrated that open-access fisheries are subject to both biological depletion and economic profit dissipation. ${ }^{5}$ These are the defining features of what Garret Hardin called the "tragedy of the commons." 6 Vernon Smith has argued that, although it is possible that open access fisheries may settle into a bio-economic equilibrium, in which the species and the commercial industry are preserved, economic profits will be fully dissipated and it is also possible that open access may result in species extinction. ${ }^{7}$ Full profit dissipation was the fate of the Dutch commercial industry. Extinction was the fate of the eastern Arctic Bowhead.

The implication of Gordon's and Smith's work, therefore, is that the profitability of the Dutch industry and survival of the Bowhead would have required the introduction of effort constraints capable of overcoming the tragedy of the commons. Standard fisheries models predict that in most cases a policy designed to limit effort, such that the present value of the infinite stream of economic profits earned from the exploitation of the fishery resource is maximized, will not result in stock extinction. ${ }^{8}$ However, C. W. Clark illustrated that profit maximizing effort constraints do not necessarily guarantee biological sustainability. ${ }^{9}$ According to Clark, conditional on the choice of discount rate, and techno-

\footnotetext{
5 Gordon, "Economic Theory."

${ }^{6}$ Hardin, "Tragedy," p. 1244.

${ }^{7}$ Smith, "On Models."

${ }^{8}$ Neher, Natural Resource Economics, Chapter 11.

9 Clark, "Economics."
} 
logical, environmental, and marketing conditions, profit maximizing resource management may still result in stock extinction.

From this brief review of the theoretical literature we may conclude that, although nothing is unequivocal, theoretically optimal regulation of the eastern Arctic Bowhead hunt may not have involved a trade-off between economic and environmental objectives. ${ }^{10}$ It is possible that optimal management designed to overcome the tragedy of the commons may simultaneously maximize profits and save a species that would otherwise be hunted to extinction. ${ }^{11}$

THE COMMERCIAL PURSUIT OF THE EASTERN ARCTIC BOWHEAD

FROM 1600-1900

\section{A Brief History}

In 1596 William Barrents discovered a small island he named Spitzbergen, situated north of Iceland and east of Greenland. This island has many harbors, and, in 1596, there was a large resident population of Bowhead whales in the waters nearby. ${ }^{12}$ When he returned to Europe Barrents promoted Spitzbergen as a potential location for commercial whaling.

Prior to Barrents discovery the only significant European commercial whaling industry was maintained by Basque whalers on the southwest coast of France, and at times off the northeast coast of North America. This small-scale industry was exclusively shore based. Shore-based whaling involved the search for whales from high masts erected on the beach, overlooking the sea. When whales were spotted close enough to permit pursuit, long boats with four or six oarsmen, a harpooner, and a steersman set out. If a long boat managed to get close to a whale, the harpooner would stand in the bow and throw the harpoon, which was attached to a six-foot-long lance, into the whale. The harpoons were connected to a rope of up to 300 fathoms, which was passed around a bollard in the bow of the long boat for resistance. If successfully struck, the whale would dive in an effort to escape. When the whale next surfaced for air, more long boats would converge and more harpoons would be launched to increase the resistance on the diving whale. When the whale became exhausted, lances were used to complete the kill. The whale's tail was removed immediately after capture because it made pulling the dead whale more difficult and it had no commercial value. The whale

\footnotetext{
${ }^{10}$ Scott, Natural Resources, pp. 63-64.

${ }^{11}$ Tietenberg, Environmental, pp. 87-92.

${ }^{12}$ Proulx, Whaling in the North Atlantic, p. 27.
} 
would then be towed back to a shore-based whaling tent where it would be butchered, and the oil and bone processed.

In 1602 the Dutch government responded to Barrents's promotion of eastern Arctic whaling by granting a monopoly charter to whale in the North Atlantic, including Spitzbergen, to the Noordsche Compaigne. ${ }^{13}$ However, rather than bear the risks associated with the journey to Spitzbergen, this company operated a tiny whaling industry off the north coast of the Netherlands for the next five years. In 1607 Henry Hudson returned to England with confirmation of the rich whaling grounds around Spitzbergen. ${ }^{14}$ Hudson was adamant that the island's harbors were ideal for shore-based whaling operations. After some success enjoyed by British whalers, there were soon Dutch, British, German, and Basque whaling operations racing to reach Spitzbergen's best harbors at the start of each season. These European whalers set out for the eastern Arctic in early spring and returned to their home ports in late summer with whale oil and baleen (whalebone) that had been processed in their whaling tents on the beaches of Spitzbergen.

By 1645 the Dutch government had seized on the idea of training sailors for naval service by encouraging whaling voyages. To achieve this, a number of measures were introduced between 1645 and 1650 . These measures included revoking the monopoly charter of the Noordsche Compaigne, imposing a 4-percent import duty on all foreign whale products flowing into the Netherlands, outlawing the use of foreign sailors on Dutch whaling vessels, outlawing the use of foreign supplies or equipment on Dutch whaling vessels, and forcing Dutch whalers to trans-ship all whale products through Dutch ports. ${ }^{15}$ These Dutch policies coincided with two developments in the Spitzbergen whaling industry. By 1650 the whales in the harbors and the waters around Spitzbergen were becoming scarce. This meant that shore based whaling was becoming infeasible. The British, Germans, and Basques abandoned their harbors, leaving the entire island to the Dutch, who continued to pursue the whales further and further from shore. By 1660 the Dutch had vacated their shore-based whaling stations on Spitzbergen as well, but, rather than leaving the industry all together, they began the first large-scale commercial pelagic whaling industry, hunting Bowhead whales in the waters between Spitzbergen and the east coast of Greenland from onboard their whaling vessels. Between 1660 and 1750 the Dutch operated the largest European whaling industry.

\footnotetext{
${ }^{13}$ Jenkins, History of the Whale, p. 126.

${ }^{14}$ Davis, Gallman and Gleiter, In Pursuit, p. 31.

${ }^{15}$ Jenkins, History of the Whale, pp. 139-40.
} 
For the purposes of our investigation of the relationship between policy, profit dissipation, and stock depletion, 1719 is a particularly important date during the era of Dutch dominance. In 1719 Dutch whalers diversified effort away from the Greenland-Spitzbergen stock of Bowhead that they had been pursuing for almost 60 years, and began hunting from another stock of Bowhead whales resident in Davis Strait, between the west coast of Greenland and Labrador. This diversification effort occurred when declining stock levels on the east coast of Greenland had lowered rents per ship enough to encourage some vessels to undertake the longer voyage and greater risk associated with hunting from the Davis Strait stock. From 1719 through 1780 rents per ship earned hunting from the Greenland-Spitzbergen stock and the Davis Strait stock were approximately equal. This suggests not only rational effort allocation between the two stocks, but also that participants in the industry realized that a reduction in effort could increase both stock and profit levels.

Between 1660 and 1750 Hamburg was the only significant nonDutch whaling port. The Germans rarely outfitted more than 10 percent of the global whaling fleet during this era. The vast majority of the remaining $90 \%$ of whaling vessels came from one of the four major Dutch whaling ports: Amsterdam, Rotterdam, Sardam, or Ryp. ${ }^{16}$ Despite the size of their fleet, 1733 marked the beginning of the end of Dutch whaling supremacy. In an effort to emulate the Dutch government's success in encouraging the training of native-born sailors on whaling voyages, the British government began offering a bounty of 20 shillings per ton for any British whaling vessel over 200 tons that employed a full crew of native-born sailors. ${ }^{17}$ By 1749 , after repeated increases in the level of subsidization, there was a substantial, and growing, fleet of British whaling vessels competing for the rapidly depleting stocks of eastern Arctic Bowhead. Over the next 50 years, despite reductions in the bounty offered by the government and the fact that both the Dutch and German fleets were having more and more trouble harvesting enough blubber to make their voyages profitable, the British industry continued to expand. ${ }^{18}$ After 1783 the number of Dutch whaling vessels declined rapidly.

By 1803, after a number of years of low profits, continued military and naval entanglements in Europe, and intense competition from British vessels, the commercial Dutch pelagic whaling industry shut down.

\footnotetext{
${ }^{16}$ Proulx, Whaling in the North Atlantic, pp. 35 and 55.

${ }^{17}$ Scorsby, Account of the Arctic Regions, pp. 72-87, provides a detailed account of the specific features of British subsidy policies at the turn of the nineteenth century.

${ }^{18}$ Ibid., p. 86, and de Vries and van der Oude, First Modern Economy, p. 264.
} 
Early in the nineteenth century, American whalers periodically hunted the Greenland-Spitzbergen and Davis Strait stocks, but only the British continued to exploit these stocks intensively. By the late-1820s the eastern Arctic stocks had been hunted to the brink of extinction. After 1830 very few British and American vessels continued to hunt the remaining whales from these stocks. By 1911 all commercial exploitation of the eastern Arctic Bowhead stocks ceased.

\section{Products Derived from the Bowhead Whale}

Two products were extracted from Bowhead whales; whale oil and baleen. The whales' blubber was boiled and refined into whale oil, which was used primarily as a lubricant and a luminant. Virtually all of the oil extracted from Bowhead whale blubber burned poorly and was exceptionally foul smelling. This meant that Bowhead whale oil was an inferior substitute for comparable products refined from vegetable oils, or the blubber obtained from the head of Sperm whales, called spermaceti. ${ }^{19}$

Baleen whales, such as the Bowhead, have strong but flexible cartilage hanging from their upper jaw. They use this cartilage like a sieve to strain food out of seawater they take into their mouths. This cartilage, or whalebone, was removed from captured baleen whales and used in a wide variety of products that today would use wire or springs. Typically whalebone accounted for less than 10 percent of the value of a captured whale.

\section{Early Pelagic Whaling Technology}

Pelagic whaling during the seventeenth, eighteenth, and nineteenth centuries was similar to shore-based whaling during the earlier era, except that the whales were spotted from the masts onboard whaling vessels and the long boats set out from these ships, rather than from shore. Blubber and bone were removed from the whales as they were partially suspended along the side of the vessel and, due to the fear of fire at sea, there was no processing of the blubber onboard Dutch vessels. British and American whalers began processing blubber, using try-works erected on the upper deck, during the early-nineteenth century. This innovation allowed whaling vessels to participate in multi-season voyages. Despite the advantages associated with multi-season voyages, the Dutch whalers who hunted the eastern Arctic Bowhead stocks simply harvested and stored the blubber in casks until the end of the season, at

\footnotetext{
${ }^{19}$ Exceptions to this rule included oil rendered from freshly butchered whales, which earned a premium price. See Davis, Gallman, and Gleiter, In Pursuit, pp. 28-31.
} 
which time it was unloaded at the whaling vessels' home ports in Europe and processed into whale oil. ${ }^{20}$ Therefore, although there were continuous improvements in both the physical and human capital employed, from the late-seventeenth until the early-nineteenth century Dutch pelagic whaling techniques were fairly static.

The whaling vessels from this period had standard physical characteristics. They averaged 200-300 British tons, carried approximately 40 crew and officers, and could launch between four and six long boats. Most of the crew was paid a fixed amount per month, whereas the officers and harpooners were paid a fixed amount plus a share of the oil captured. ${ }^{21}$ This revenue-sharing arrangement spread the risks involved in financing a whaling expedition to include those onboard with the most control over an expedition's success or failure. ${ }^{22}$ The ships of the Dutch whaling fleet sailed from their home ports in early spring and reached the ice cap east of Greenland and in Davis Strait as the spring break up was occurring. They would then sail with the ice flows south along Greenland's coasts, hunting the Bowhead that were confined within narrow channels of open, ice-free water. At the southern tip of Greenland they would turn north again to repeat the circuit. Two or three circuits could be completed each season.

We will revisit this brief discussion of the historical and technological context in which European pelagic whalers hunted from the eastern Arctic stocks of Bowhead whales when we discuss the relevance of the required assumptions implicit in standard fisheries models.

\section{A SIMULATION MODEL DESCRIBING THE EXPLOITATION OF THE EASTERN ARCTIC BOWHEAD}

To facilitate our investigation of the relationship between the biological sustainability of the Greenland-Spitzbergen stock of Bowhead whales and the profitability of the Dutch commercial industry exploiting these whales, we have constructed a simulation model. ${ }^{23}$ This model explicitly links the biological and economic features associated with the exploitation of the Bowhead. We use our model to conduct counterfac-

${ }^{20}$ Ibid., pp. $36-37$.

${ }^{21}$ Jenkins, History of the Whale, pp. 158-59.

${ }^{22}$ The American practice of spreading risks to an even greater extent by including the captains of whaling vessels as part owners is discussed by Craig and Knoeber, "Manager Shareholding."

${ }^{23}$ We focus on the Dutch exploitation of the Greenland-Spitzbergen stock to both simplify the modeling exercise, and to highlight the impact that a single, well-defined fleet had on a homogenous, geographically distinct whale stock. On average, the Dutch fleet accounted for 75.5 percent of the Greenland-Spitzbergen aggregate catch. On average, 70.7 percent of the aggregate Dutch catch was taken from Greenland-Spitzbergen stock. 
tual experiments, in which we impose various hypothetical regulatory regimes and study the impact on stock depletion and industry profits.

\section{Reconstructing the Whale Population}

As a first step in the formulation of our simulation model we require a biological model capable of describing the evolution of a geographically distinct whale stock, subject to human predation. An effective model should allow us to derive an estimate of the "pristine stock" of eastern Arctic Bowhead whales, reconstruct the history of their population, and therefore, help us to understand the chronology of their extinction.

The early pelagic whaling industry left abundant records - if not whales - and many investigators have used these to estimate pristine stock levels; that is, the population immediately before commercial exploitation by Europeans. The range in estimates for the GreenlandSpitzbergen stock is very large. Edward Mitchell put the pristine stock at about $25,000 .^{24}$ This was repeated in various reports of the International Whaling Commission and has been accepted with slight variations by leading economic historians. ${ }^{25}$ Recently, Louwrens Hacquebord used an updated methodological approach that raised the estimate to $46,000 .{ }^{26}$ We believe that the pristine whale population in the waters between Spitzbergen and the east coast of Greenland was even higher still — on the order of 63,380 adult whales in 1605 .

The basic data with which we construct our population estimates are the records of whales caught each year since the early seventeenth century. We have created an annual data base running from 1605 until 1911 that includes the number of ships hunting whales, the number of whales caught, the quantity of bone and oil produced, and the prices of those products. Separate figures were assembled for the GreenlandSpitzbergen and Davis Strait stocks. The information on the number of whales caught and the number of ships that hunted them are intended to be comprehensive and include returns from the Netherlands, Britain, Germany, and the United States. Information on whaling by other countries has been included when available.

In most cases, the data were taken from annual lists of the number of ships participating in the whale hunt and the numbers of whales caught. S. Ricard provides a good example of contemporary interest in information about commercial whaling in the Netherlands. ${ }^{27}$ More recently C.

\footnotetext{
${ }^{24}$ Mitchell, Initial Population Size.

${ }^{25}$ de Vries and van der Oude, First Modern Economy, p. 263.

${ }^{26}$ Hacquebord, "Three Centuries."

${ }^{27}$ Ricard, Traite Generale.
} 
de Jong has conducted exhaustive studies of Dutch, British, and German historical whaling records. ${ }^{28}$ Although we can document the Dutch industry thoroughly, the data available for the British industry were not complete. Lists of the number of voyages and their results are available for Hull from as early as 1733, but not for other ports. However, the British statement of trade distinguishes trade from the "fisheries," which was the eastern Arctic whaling grounds. The information from Hull (about 37 percent of the total, on average) has been scaled up in proportion to the national consumption of domestic whale products to estimate the size of the entire British fleet.

To estimate a pristine stock level, and annual changes in this stock level, we use our data with a simple model of population dynamics. We have followed Jon Conrad in our use of a delayed difference recruitment model to reconstruct the Spitzbergen-Greenland Bowhead population. ${ }^{29}$ This model is an adaptation of M. B. Shaefer's growth model, in which an unvarying birth and adult mortality rate is combined with infant mortality that increases with population size to generate a parabolic growth function. ${ }^{30}$ Our biological model determines population size in year $t+1$ as a function of population size in year $t$, harvest in year $t$, and parameters $^{31}$

$$
p_{t+1}=p_{t}+b p_{t-T}\left(1-\left(p_{t-T} / p_{\max }\right)^{\alpha}\right)-d p_{t}-\theta h_{t}
$$

Parameter estimates for the Greenland-Spitzbergen Bowhead stock have been derived from research on the Bowhead stock that continues to exist in the Bering Sea, and they have been compared to similar parameter estimates for other northern whale species. ${ }^{32}$ More specifically, we have assumed that the rate of natural increase was 7 percent per year; $b=$ 0.07 ; death from natural causes occurred at 5 percent per year; $d=0.05$; additions to the stock peaked at slightly more than half of the maximum environmental holding capacity; $\alpha=2.39 ; 120$ percent of the whales actually harvested were struck and killed; $\theta=1.20$; and the age at sexual

\footnotetext{
28 de Jong, "Hunt."

${ }^{29}$ Conrad, "Bioeconomics."

${ }^{30}$ Schaefer, "Some Considerations."

${ }^{31}$ We are unable to employ a more sophisticated biological model because we do not have any information on sex ratios, age distributions, or food availability. We are currently working on an extension of this population model that incorporates determinants of stock size that are related to temperature measures derived from ice core data.

32 Conrad, "Bioeconomics," table 1; Chapman, "Evaluation," p. 283; Clark and Lamberson, "Economic History," p. 109; and Amundsen, Bjorndal, and Conrad, "Open Access,” p. 173.
} 
maturity was five years; $T=5 .^{33}$ The maximum environmental holding capacity; $p_{\max }$; is determined within the model.

Our population estimation procedure began with an assumed, constant pristine stock in 1605 . We then used equation 1 to derive stock levels for every year until 1911; the year in which the final British whaling voyage to the eastern Arctic spent an entire season in the traditional whaling areas and landed no whales. ${ }^{34}$ Under the assumption that there were no more than 1,000 Bowhead whales remaining in the Greenland-Spitzbergen stock in 1911, we calculated that the pristine stock level was 63,380 adults. To determine how sensitive our pristine stock estimate is to changes in the underlying parameters, our catch estimates, and the assumed stock level in 1911, we have repeated the estimation procedure using other plausible parameters, estimates, and assumptions. Our pristine stock estimate does not vary substantially under any of our sensitivity tests. ${ }^{35}$

Figure 1 plots our reconstruction of the Greenland-Spitzbergen stock of Bowhead whales from 1605 through 1911. The stock appears to have declined rapidly in the late seventeenth century as the Dutch pelagic industry expanded into a dominant position relative to the other European whaling nations. The stock decline was attenuated through the mideighteenth century as the Dutch industry matured. This slowdown in the rate of depletion raises the possibility that the industry was approaching, but never attained, a stable bio-economic equilibrium. The third phase of decline began in the late eighteenth century when British whalers forced the Dutch from their dominant position. The British very rapidly hunted the whales to the brink of extinction. By 1828 we estimate that there were fewer than 1,500 Bowhead whales remaining in the waters between the east coast of Greenland and Spitzbergen. In the sections that follow we will touch briefly on possible reasons why the Dutch were unable to maintain a bio-economic equilibrium, and why the British were so lethal to whales. ${ }^{36}$

\section{A Model of the Dutch Pelagic Whaling Industry}

Because hunting the eastern Arctic Bowhead was a commercial venture, the extinction of the stock was an economic, as well as a biological

\footnotetext{
${ }^{33}$ A 20-percent allowance for whales that were killed, but not landed, is consistent with other work on early pelagic whaling. For example see Mitchell, Initial Population Size, p. 20; Ross, "Annual Catch," p. 91; and Davis, Gallman, and Gleiter, In Pursuit, p. 140. Lowering the assumed "killed but lost" parameter to 10 percent reduces our pristine stock estimate to 58,102 .

${ }^{34}$ Ross, "Annual Catch," table 3.

${ }^{35}$ Allen and Keay, "First Great Whale Extinction," p. 453.

${ }^{36}$ For more details on the evolution of the stock estimates see ibid, pp. $454-55$.
} 


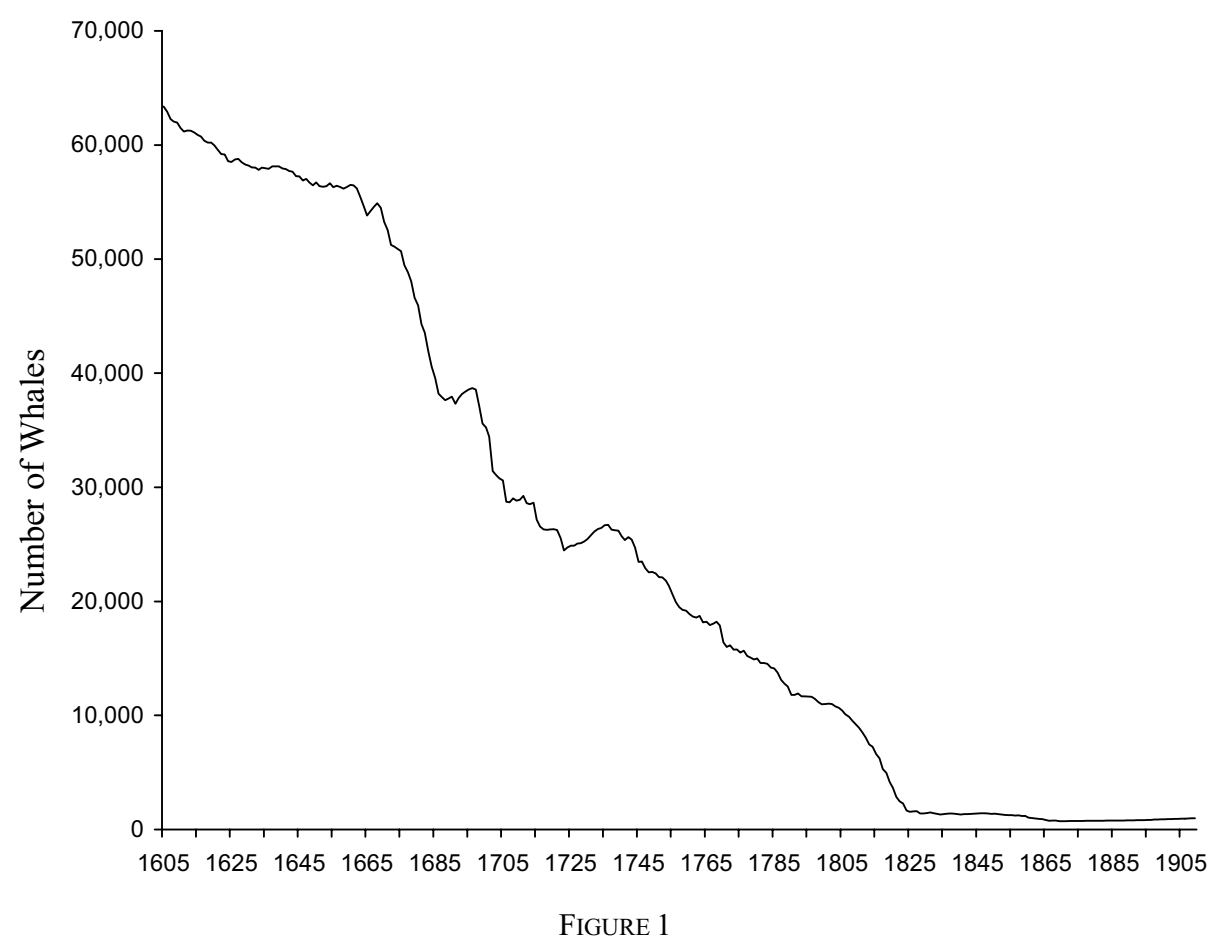

EASTERN ARCTIC BOWHEAD STOCK RECONSTRUCTION

Note: See the text for discussion of the reconstruction.

event. To explore the economic incentives inherent in the commercial pursuit of whales, and the policy environment in which early pelagic whalers made their decisions, we have estimated an econometric model of the Dutch whaling industry. ${ }^{37}$ The specification of the industry model highlights the relationship between the economic and natural environments.

Our industry model is summarized by the flow chart provided in Figure 2 . The number of whales captured in a season was dependent on the number of whales in the water, the number of ships pursuing them, and the technology employed in the pursuit. We estimated a production function to represent this relationship mathematically. More whales, more ships, and better technology implied a bigger catch. To explore the effect of climatic conditions on whaling, we also included a variable representing the temperature in Greenland. ${ }^{38}$ Higher temperatures were

\footnotetext{
${ }^{37}$ The specification of the equations that make up our simulation model were inspired by the typical structure of a standard optimal control fishery model. However, the functional forms have not been derived from the solution to any particular dynamic optimization problem.

${ }^{38}$ Our temperature variable was derived from an ice core sample taken on the east coast of Greenland. See www.nicl.usgs.gov.
} 
FIGURE 2

SIMULATION MODEL OF DUTCH WHALING INDUSTRY

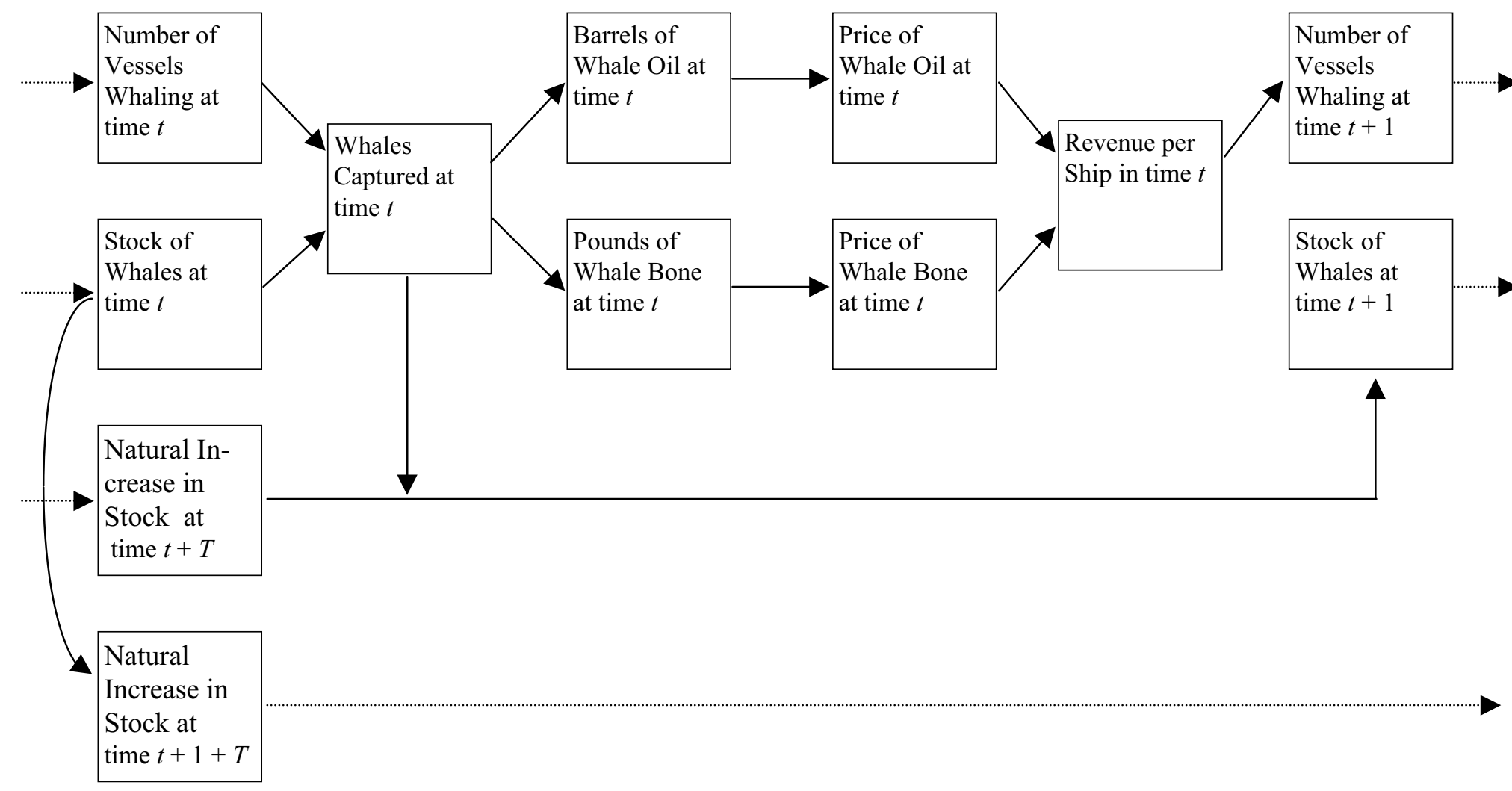

Notes: See the text for discussion of the construction of the simulation model. 
associated with earlier and more ragged spring ice break ups, and more treacherous sailing conditions. The number of whales captured tended to be lower when the Arctic was warmer. In this respect, global warming may have been to the whales' advantage. ${ }^{39}$ As a final determinant of catch, we added a random variable drawn from a normal distribution with zero mean and a standard deviation equal to $0.668 .^{40}$ This random component was included to capture the volatility associated with "luck" in the hunt.

The quantity of blubber and bone, the products extracted from the Bowhead whale, was not a constant multiple of the number of whales harvested. We estimated equations to represent the yield of these products and found that oil per whale declined over time. This suggests that the drop in the whale population over the period of exploitation led the Dutch to hunt smaller, younger whales. We also found that, because warmer weather meant more food for the whales and hence more blubber and bone, yields increased with temperature in the Arctic.

When the whalers returned to the Netherlands, they processed their blubber in rendering plants located in the main whaling ports. The refined oil and cleaned bone were then sold on the domestic market. Oil and bone prices depended on the volume put on the market and the strength of demand. We estimated inverse demand curves (in which price is a function of quantity sold) to summarize these factors. ${ }^{41}$

The demand curves reveal two important features of the market. First, we included the price of rape seed oil in the demand for whale oil, because the two kinds of oil were close substitutes for one another. Indeed, the statistical analysis revealed a high cross-price elasticity of demand, which implies that changes in the price of vegetable oil had a big impact on the price of whale oil. Second, we included the real wage in the demand curves for both products, because real wages measure the purchasing power of consumers and their ability to bid up prices. The findings were perverse; in both cases, higher consumer income implied lower demand. This is the reverse of the usual situation of "normal"

\footnotetext{
${ }^{39}$ Despite the obvious relationship between environmental conditions and birth and death rates, we have not yet included our temperature variable in our population reconstruction. Including environmental conditions directly in our biological model remains an interesting avenue for future research.

${ }^{40}$ The mean and standard deviation for the volatility component of the catch function have been chosen to match the errors from the econometric estimation. This volatility parameter represents the only stochastic element within our simulation model.

${ }^{41}$ Because whale oil was a small share of the aggregate market for luminant and lubricant products, we have assumed that whale oil prices were endogenous and rape seed oil prices (our proxy for luminant and lubricant substitutes) were exogenous. Because storage across seasons was unusual, we have assumed that whale products harvested during only the current year were exogenous determinants of price.
} 
goods, for which higher income implies higher demand. The result, however, is not surprising, at least in the case of the relatively low quality whale oil derived from the eastern Arctic Bowhead. The statistical results tell us that consumers bought higher quality alternatives to Bowhead whale oil when they could afford to do so.

With the sale of the oil and the bone, the whaling season is at an end. The seasons have both an economic and a biological link in our model, in the sense that events in the market and in the water during the current year shape the events during the next year.

The biological link is the change in the whale population. We used our delayed difference recruitment model to predict the evolution of the whale population, taking into account the number of whales our model suggests were killed each year. Accumulating these predictions gives a simulated history of the whale population that is different from the actual history. The biological link allows us to explore the impact that policies designed to maximize the profitability of the commercial industry have on the sustainability of the Bowhead population.

The economic link is summarized by our effort equation, which expresses the number of whaling vessels that depart in the spring as a function of variables in the previous year. ${ }^{42}$ One variable is whaling revenue. Multiplying the quantities of oil and bone by their prices gives the revenue earned on a whaling voyage. Subtracting costs gives profits. Although past profit per ship is the expected predictor of the number of ships setting out for Greenland, our cost data are incomplete. ${ }^{43}$ Due to our concern about the available cost data, we have relied exclusively on revenue-per-ship figures in the construction of our effort equation. ${ }^{44}$ During the period of Dutch ascendancy and effort diversification, 17191749 , we found that increases in average revenue per ship in one year implied more effort the next. This economic link allows us to explore the impact of various policy tools, including direct effort constraints and revenue taxation, on the profitability of the whaling industry.

A second variable that was important in explaining the size of the whaling fleet was its size in the previous year. Whereas most vessels in the seventeenth- and eighteenth-century Dutch fleet could have been shifted between activities, whaling ships had a distinctive design that

\footnotetext{
${ }^{42}$ Although our effort equation implies the solution to an individual's participation decision based on a value function, it has not been derived from any specific optimization exercise.

${ }^{43}$ Scorsby, Account of the Arctic, p. 156; Jenkins, History of the Whale, p. 58; and de Vries and van der Oude, First Modern Economy, table 7.3.

${ }^{44}$ We have used all of the available information on costs to estimate cost-per-ship and processing-cost functions, which we assume the regulator uses to simulate profits. However, we are uncomfortable using these functions to predict costs, and hence profits, which we would in turn need to estimate effort functions.
} 
protected them against the ice, fitted them for butchering the whales and storing the products, and facilitated the rapid deployment of the long boats that pursued the whales. Design specificity ensured a dedicated whaling fleet. The same was true of the captains, officers, harpooners, and some tradesmen. These people had specific knowledge and skills that were particularly valuable in whaling and not especially useful in other activities. Although many sailors were hired on a casual basis, the core of the whaling labour force was not readily mobile. The irreversibility of the physical and human capital employed in the Dutch whaling fleet is common among fishing industries. ${ }^{45}$ The specificity of capital and skills in the whaling industry is manifest in the statistical results as strong persistence in the size of the fleet from one year to the next, irrespective of the profits realized.

The industry model, therefore, predicts the number of ships setting out each year, the number of whales captured, the volume of whale products brought to market, and the prices of these products. The exogenous variables are the price of rape seed oil, population, real income, taxes and subsidies, and Arctic temperature, as well as the size of the whaling fleet and the whale population in the previous year. With the industry model and our delayed difference recruitment model we can simulate the history of Dutch exploitation of the eastern Arctic Bowhead by specifying initial values for the whale population and fleet size, and time paths for the exogenous variables (see Table 1).

A test of the model is to use the actual values of the exogenous variables in a simulation. If the model is "good," then it should replicate the historical trajectories of the endogenous variables it explains. The model does pass this test. ${ }^{46}$

\section{LESSON ONE: OPEN ACCESS RESULTS IN PROFIT DISSIPATION AND STOCK DEPLETION}

Although it is possible for an open access industry to be in a bioeconomic equilibrium with a stable whale population and positive effort levels, it is not inevitable, and the Dutch whaling industry was never in such a situation. Even before the entry of the British during the mideighteenth century, the Dutch were overexploiting the stock, and the Bowhead population was falling. This suggests that, even without the entry of the British, the whales would have eventually been hunted to extinction.

\footnotetext{
${ }^{45}$ For discussion see Clark, Clarke, and Munro, "Optimal Exploitation."

${ }^{46}$ Allen and Keay, "First Great Whale Extinction," p. 462.
} 
TABLE 1

A SIMULATION MODEL OF DUTCH EXPLOITATION OF THE EASTERN ARCTIC BOWHEAD

\begin{tabular}{|c|c|}
\hline Variable & Equation \\
\hline opulation & $p_{t+1}=p_{t}+0.07 p_{t-5}\left(1-\left(p_{t-5} / 107053\right)^{2.39}\right)-0.05 p_{t}-1.20\left(h_{t}+H_{t}\right)$ \\
\hline & $\begin{array}{l}\ln h_{t}=0.825 \ln t+0.960 \ln e_{t}+0.528 \ln p_{t}-3.027 \ln C^{\circ}{ }_{t}+\Omega_{t} \\
\ln H_{t}=1.375 \ln t+0.440 \ln e_{t}+0.313 \ln p_{t}-3.200 \ln C^{\circ}{ }_{t}\end{array}$ \\
\hline & $\ln o_{t}=-0.429 \ln t+1.026 \ln h_{t}+2.083 \ln C^{\circ}{ }_{t}$ \\
\hline & $\ln b_{t}=0.134 \ln t+1.037 \ln h_{t}+1.765 \ln C_{t}^{\circ}$ \\
\hline ce & $\ln p o_{t}=0.778 \ln t-0.260 \ln \left[\left(o_{t}+O_{t}\right) / p o p_{t}\right]+0.236 \ln p s u b_{t}-0.386 \ln r w_{t}$ \\
\hline & $\ln p b_{t}=0.704 \ln t-0.196 \ln \left[\left(b_{t}+B_{t}\right) / p o p_{t}\right]-1.596 \ln r w_{t}$ \\
\hline ffort & $\ln e_{t+1}=0.007 \ln t-0.015 \ln t^{2}+0.387 \ln \left(\mathrm{rev}_{t} / e_{t}\right)+0.793 \ln e_{t}-0.579 \ln C^{\circ}{ }_{t}$ \\
\hline \multicolumn{2}{|c|}{$\begin{array}{l}\text { Notes: } \\
H_{t}=\text { number of Greenland-Spitzbergen whales harvested by all non-Dutch whalers. } \\
O_{t}=\text { amount of whale oil processed from whales harvested outside of the Greenland- } \\
\text { Spitzbergen hunting ground, sold on the Amsterdam market. } \\
B_{t}=\text { amount of bone processed from whales harvested outside of the Greenland-Spitzbergen } \\
\text { hunting ground, sold on the Amsterdam market. } \\
\text { All other variables are defined in the text. }\end{array}$} \\
\hline
\end{tabular}

Because the Bowhead were swimming freely in a large area of international water, property rights pertaining to the whales were poorly defined and ownership was impossible to enforce. This was true as early as the first half of the seventeenth century, when the Dutch Noordsche Compaigne made an effort to enforce the monopoly charter they had been granted in 1605 over eastern Arctic whaling based on the island of Spitzbergen. Their inability to exclude other whalers from participating in the hunt made these efforts fruitless. ${ }^{47}$ The absence of enforceable property rights makes most environmental assets "open access resources," for which all of the returns associated with conservation cannot be captured by any single individual because others cannot be excluded. The implication is that, for most environmental assets, including the Bowhead whale, there will be too little conservation. In practice, this "tragedy of the commons" means that too many vessels will pursue too few whales, resulting in over-exploitation and profit dissipation. For the Dutch this was exacerbated because the inputs employed in the industry were not readily transferable into other occupations. These inputs, therefore, remained in the industry even as stock and profit levels became very low, and ultimately fell below zero. ${ }^{48}$

\footnotetext{
${ }^{47}$ Jenkins, History of the Whale, p. 139.

${ }^{48}$ We have estimated annual profits as total revenue; $\left(P_{\text {oil }} \mathrm{x}\right.$ Barrels Oil $+P_{\text {bone }} \mathrm{x}$ Pounds Bone); less predicted total cost; (Estimated Cost Per Ship x Number of Ships + Estimated Cost Per Barrel x Number of Barrels). Because we do not have a complete time series for costs, we have used econometrically estimated cost per ship and cost per barrel equations, in which costs are a function of the stock level, the stock level squared, time (as a proxy for technical change), time squared, temperature, and real wages in Amsterdam, to derive annual cost estimates. In-
} 
We have performed two "benchmark" simulations that clearly illustrate the impact of open-access exploitation on the GreenlandSpitzbergen Bowhead stock and the Dutch commercial whaling industry. In the first benchmark we simulated the Dutch industry presuming no regulatory constraints on effort, the maintenance of the Dutch import duty and subsidy policies, and the entry of British whalers after $1750{ }^{49}$ We found that in this "Benchmark 1" simulation the Greenland Bowhead stock fell below 1,500 individuals in 1815 and the Dutch industry suffered aggregate losses over the 1719-1815 period equal to -2.63 million guilders, in present value terms, assessed in 1719 with a 5 percent discount rate. ${ }^{50}$ The results from this first benchmark closely resemble the population history mapped out by our initial stock reconstruction, in which the Bowhead population drops below 1,500 individuals in 1828, and our profit estimates derived from the observed variables, in which the industry suffers losses over the 1719-1803 period equal to -2.11 million guilders, in present value terms. Benchmark 1, therefore, clearly illustrates the stock depletion and profit dissipation inherent in an openaccess environment with international competition and government subsidy supports.

In our second benchmark simulation we investigated the possibility that it was the presence of British competition after 1750 and subsidy supports, rather than open access, that led to the demise of the Bowhead. More specifically, we removed the impact of British participation, and Dutch duties and subsidies from our model (see Table 2).

The removal of the British fleet from the model eliminates the possibility that international competitive pressure or strategic behaviour could have been responsible for the pattern of Dutch exploitation. The exclusion of the British could have come through the use of naval power by the Dutch to enforce a claim of national sovereignty over the eastern Arctic whaling ground, or more likely, collusion among the Dutch and British whalers. This collusion could have been imposed as a formal, bilateral whaling agreement between the two governments, or as

creases in stock levels and technology reduce costs, but at a decreasing rate. Increases in temperature and real wages also increase hunting costs. For information on costs see Scorsby, Account of the Arctic Regions, p. 156; Jenkins, History of the Whale, p. 58; and de Vries and van der Oude, First Modern Economy, table 7.3.

${ }^{49}$ In "Benchmark 1" the observed British participation is an exogenous variable in our model.

${ }^{50}$ Economic theory predicts that profits earned from an open-access industry will be driven to zero. In our benchmark simulations, and the observed industry performance, profits are less than zero because of the persistence in the effort function; vessels continue to participate even after the industry suffers losses. On average the Greenland-Spitzbergen stock generated approximately 1.71 million guilders annually in total revenue. An aggregate loss of 2.63 million guilders, therefore, is equal to the revenue generated over approximately 1.5 years of industry operation. 
TABLE 2

BENCHMARK SIMULATIONS OF THE DUTCH WHALING INDUSTRY

\begin{tabular}{lcc}
\hline \multicolumn{1}{c}{ Simulation Title } & Coverage & PV Profits \\
\hline Initial reconstruction & $1719-1828$ & $-2,113,348$ \\
Benchmark 1 & $1719-1815$ & $-2,630,865$ \\
Benchmark 2 & $1719-1846$ & $-1,973,141$ \\
\hline
\end{tabular}

Note: PV profits are in guilders. For explanation of simulation titles see the text.

an informal agreement among whaling captains. The removal of the duty and subsidy supports eliminates the effects of government intervention from our simulation.

We found that in this "Benchmark 2" simulation the eastern Arctic Bowhead stock fell below 1,500 individuals in 1846 and the present value of the Dutch industry's aggregate losses over the 1719-1852 period were equal to -1.97 million guilders. The results from this second benchmark simulation suggest that without international competition and government intervention Dutch losses would have been slightly lower, and the stock would have lasted slightly longer, but even still, profits would have been totally dissipated and the stock was doomed; the tragedy of the commons continues to hold.

From these benchmark simulations we can identify our first lesson from the extinction of the eastern Arctic Bowhead: even in the era prior to the introduction of steam power into commercial whaling, bioeconomic equilibria with positive stock levels may have been possible, but they were not universal. Indeed, exploitation in an open-access environment, without international competition or any government intervention would have led to the complete dissipation of Dutch profits and the extinction of the eastern Arctic Bowhead.

\section{LESSON TWO: SIMULTANEOUSLY MAXIMIZING PROFITS AND SAVING THE WHALES}

The absence of well-defined property rights associated with open access, and the subsequent profit dissipation and over-exploitation, may be overcome by an institutional arrangement that successfully restricts access to the resource. Access restrictions can facilitate the internalization of all the benefits associated with conservation. In other words, institutions that exclude those who do not bear any of the costs of conservation, allow those who do bear the costs to capture all of the returns to their efforts. Restrictions on participation with this internalization as a 
goal can solve the problem of profit dissipation, and potentially, but not necessarily, stock depletion. ${ }^{51}$

During the seventeenth and eighteenth centuries there were no regulations designed to constrain whaling effort in the Netherlands or Britain. ${ }^{52}$ Although there may have been some private collusion among Dutch whalers designed to punish those captains who insisted on taking young whales or nursing mothers, given the final outcome for the stock and the Dutch industry, these restrictions were obviously not effective in the long run. ${ }^{53}$

The success of any regulatory regime is dependent on the biological, economic and technological context in which asset exploitation is occurring. To pursue our investigations we must fully specify the counterfactual "regulatory environment." This specification requires four additional assumptions. Our assumptions have been chosen to closely approximate the regulatory environment implied by standard fisheries models. ${ }^{54}$ First, we have based all of the counterfactual experiments on our second "no British-no subsidies-open access" benchmark simulation. Using this simulation as a base allows us to start with a "clean slate," in the sense that we need not be concerned with the behavior of any participants who are not explicitly modeled within the simulation, and we need not be concerned with any government policies except those we wish to impose within the simulation.

Second, we initiated all of our policy experiments in 1719. This was the year in which profits earned from the pursuit of the GreenlandSpitzbergen stock of Bowhead whales fell to such an extent that effort diversification into Davis Strait became economically viable, despite the extra risks and costs associated with the longer voyages. We suggest that the Dutch whalers revealed their responsiveness to economic incentives, and their appreciation of the biological and economic impact their hunting effort was having on the Greenland stock, by extending voyages into Davis Strait. 1719, therefore, marks the first year in which we can confidently claim that the industry and potential regulators were aware of the need for some effort response to maintain the biological and economic viability of the Bowhead whale.

\footnotetext{
${ }^{51}$ Hartwick, "Intergenerational Equity," identifies the conditions under which we can expect to find profit maximization and positive stock levels for a nonrenewable resource. Dasgupta and Heal, Economic Theory, discuss the possibility that profit maximization may not be associated with stock preservation in their seminal treatment of renewable resource exploitation. Carlos and Lewis, "Property Rights," provide an empirical example in which profit maximizing behavior results in the extinction of geographically distinct beaver stocks.

52 de Jong, "Hunt of the Greenland Whales," p. 90.

${ }^{53}$ Allen and Keay, "First Great Whale Extinction," p. 474.

${ }^{54}$ Neher, Natural Resource Economics, chapter 11.
} 
Our third assumption deals with the choice of 1914 as a termination date for our policy experiments. Given the inclusion of variables designed to capture changes in technology, economic activity, and economic development over time, we are confident that our model of the Dutch whaling industry is relevant up to the late nineteenth century. However, the widespread introduction of steam power to commercial fisheries, in conjunction with the substitution of petroleum products and flexible spring steel for whale products, implies that the late-nineteenthand early-twentieth-century results derived from our model should be interpreted with caution. ${ }^{55}$ Although we do report simulated extinction dates later than 1914, we prefer to focus on the evolution of the economic and biological variables over the 1719-1914 period.

As in most of the resource management literature, we have adopted an industry capture model of government policy formation. More specifically, we have assumed that the objective of any regulatory regime would have been the maximization of the present value of industry profits derived from the entire period of eastern Arctic Bowhead exploitation. This assumption has a number of implications, including the notion that social welfare is not an objective, and hence, that biological sustainability has no value to the regulator, except through the relationship between the existence of the whales and the perpetuation of the profits associated with the industry. We have, therefore, biased our simulations against biological sustainability by ignoring any nonmarket, or social value stemming from the existence of the whales. The assumed policy objective also implies that our regulator discounts the profits, and losses, earned after 1719. By considering the "present value" of the economic profits in 1719, the regulator is implicitly assigning less importance to whalers in future generations. The intergenerational inequity of this approach has sound theoretical motives, but it further biases our simulations against biological sustainability. ${ }^{56}$ The calculation of the present value of the profits earned off the stock over the entire period of exploitation also implies that the regulator has perfect foresight. This, in turn, implies that the regulator can accurately predict not only all of the economic features of the commercial industry in every year after 1719, but the evolution of the stock in every year as well. Finally, our assumption that the sole objective of the regulator was profit maximization implies that the Dutch (and in the presence of collusion, British) government abandoned all employment objectives. In other words, by assuming that only profits matter, we have assumed that the govern-

\footnotetext{
${ }^{55}$ Bockstoce, Whales; and Scott, "I.T.Q.," p. 31.

${ }^{56}$ For detailed discussion see Porter, "New Approach."
} 
ment's interest in the whaling industry was no longer motivated by a desire to train native-born sailors for naval duty in times of war.

Armed with these four assumptions we turn our attention to the issue of profit maximization through the use of regulatory regimes. We have performed simulations with a wide range of potential regulatory regimes in our search for "optimal management." In general, only those policies that successfully restrict the number of vessels that participate in the hunt are capable of halting the dissipation of profits. More specifically, aggregate-catch restrictions, catch-per-ship restrictions, technological-change restrictions, and policies designed to reduce the price of whale oil by reducing the price of its closest substitute; rape seed oil; can successfully halt long-term stock depletion, but cannot substantially improve on the profit performance of the Dutch industry relative to the Benchmark 2 simulation. 57 The "failure" of these policies stems from the fact that any increases in profitability are transitory. A policyinduced reduction in catch levels in year $t$, for example, increases stock size in $t+T$, which increases profits in that year, encourages greater effort and consequently costs, in the next year. This in turn drives profits down, and the model quickly reverts to the time path characterized by the benchmark simulation. It is apparent, therefore, that the range of "successful" policy options is much broader if the regulator's objective is biological sustainability, rather than profit maximization. However, in this section we seek to maintain our approximation of the policy environment that typifies theoretical models by focusing our attention on the policy options that were capable of excluding vessels from participating in the hunt, and therefore, substantially increasing the aggregate profitability of the industry.

One successful regulatory approach involves the imposition of effort caps, which specify the maximum number of vessels participating in the hunt in each year. In practice these caps would likely be implemented by requiring that every vessel hold an annual licence to hunt. The regulator could then exclude vessels by restricting the number of licences that were issued in any particular year. In our model, effort is represented by the number of ships. This is a simplification; effort would actually have been a function of all inputs employed in the industry, including the number of crew members per vessel, the number of long boats per vessel, and the capacity and physical characteristics of each vessel. This implies that there would have been a heavy administrative

\footnotetext{
${ }^{57}$ For example, restricting aggregate catch to no more than 395 whales (the benchmark simulation estimates an average of 305 whales landed per year) saves the stock from extinction, but profits drop by over 78 percent to -3.5 million guilders. Indeed, the profit maximizing/loss minimizing aggregate catch restriction is to allow unfettered access to the stock.
} 
burden associated with effort caps, as an effective cap would require that regulators make the licences binding for all the determinants of effort. Our model allows us to ignore the administrative complexities because we assume that constraining the number of ships is an accurate proxy for an effective effort control.

We found that the present value of aggregate profits from the exploitation of the eastern Arctic Bowhead were maximized when participation in the hunt was limited to no more than 41 ships in every year after 1719. Between the years 1661, when the Dutch began pelagic whaling, and 1719 there were never fewer than 108 Dutch vessels on the eastern Arctic hunting grounds (excluding war years). Between 1719-1803 the Dutch whaling industry sent out just over 96 ships per year, on average. This cap, therefore, represents a dramatic reduction in the number Dutch whalers allowed to participate. However, if this cap had been imposed in 1719, and left in place until World War I, there would have been slightly more than 48,000 whales remaining in the Greenland stock and the present value of the aggregate profits from the industry would have increased to slightly less than 3.21 million guilders. It is apparent that the proposed effort cap not only returns the industry to profitability, but it successfully saves the whales from extinction. Indeed, an effort cap as high as 65 ships per year ensures biological sustainability for the Bowhead. ${ }^{58}$

The other regulatory approach we have investigated that successfully generated substantial improvements in the profitability of the industry was the imposition of revenue taxes. Because a key determinant of the whalers' participation decisions in each year was past revenue per ship, and the inputs employed in the eastern Arctic Bowhead hunt were unique and immobile, such that they could not avoid the tax, a tax on revenue reduced the incentive to participate. Unlike the effort caps, a tax policy would have been administratively straight-forward to implement. We have assumed that the tax could be imposed on the value of processed whale products brought to market. This implies that the regulator need not have been concerned with controlling the entire range of effort determinants, because the decision to participate and the characteristics of any participation would have been left in the hands of individual whaling captains. In addition, the tax policy would not require monitoring and enforcement for every vessel participating in each year, but only for the few processing plants in the major Dutch ports. A final advantage of a taxation approach, relative to the imposition of effort

\footnotetext{
${ }^{58}$ We define biological sustainability as the absence of a statistically significant negative time trend in the Bowhead population estimates after the implementation of the policies in 1719 .
} 
TABLE 3

SIMULATING OPTIMAL MANAGEMENT OF THE DUTCH WHALING INDUSTRY

\begin{tabular}{lcccr}
\hline \multicolumn{1}{c}{ Simulation Title } & Coverage & Policy & Stock 1914 & PV Profits \\
\hline Optimal effort cap & $1719-1914$ & $e \leq 41$ & 48,225 & $3,206,990$ \\
Minimum effort cap & $1719-1914$ & $e \leq 65$ & 27,615 & $2,576,505$ \\
Optimal revenue tax & $1719-1914$ & $t=46$ percent & 46,304 & $2,381,940$ \\
Minimum revenue tax & $1719-1914$ & $t=31$ percent & 27,417 & $1,946,143$ \\
\hline
\end{tabular}

Notes: PV profits in guilders. For explanation of simulation titles and policies see the text.

caps, would be the generation of tax revenue for the regulator. This revenue, which was included in our calculation of the industry's profits, could have been used to support other activities related to the industry, the economy in general, or it could have been used to reduce other socially expensive wage, sales, or capital income taxes.

We found that the present value of aggregate profits from the exploitation of the eastern Arctic Bowhead were maximized when revenue from the sale of processed whale products was taxed at a rate of 46 percent. Although the appropriation of almost half of the aggregate value of all whale products may seem extreme, the overall effect of this tax on the industry was clear; the present value of the combined profits earned by Dutch whalers and tax revenue earned by the Dutch regulator between 1719 and 1914 would have totalled more than 2.38 million guilders. The tax's effect on the biological sustainability of the Bowhead stock was equally clear; had the 46-percent revenue tax remained in place for the entire period, there would have been 46,304 Bowhead whales remaining in the Greenland stock in 1914. A tax rate as low as 31 percent could have saved the Bowhead from extinction (see Table 3).

This brings us to the second lesson we can learn from the extinction of the eastern Arctic Bowhead: the imposition of a regulation capable of restricting participation, such as a tax policy, or an effort cap, could have simultaneously halted profit dissipation and stock depletion, as long as the policy environment closely resembled the ideal inherent in standard fisheries models. Unfortunately, in our model a regulator's ability to maximize profits and save the whales concurrently is dependent on the maintenance of the ideal policy environment.

\section{LESSON THREE: ACHIEVING DYNAMIC EFFICIENCY UNDERMINES BIOLOGICAL SUSTAINABILITY IN A MORE REALISTIC POLICY ENVIRONMENT}

The four assumptions we made prior to the simulation of the optimal management programs imply four features of the policy environment that are obvious deviations from the actual mid-seventeenth- to early- 
nineteenth-century economic, social, and political environment described in this article. These deviations would not be worthy of note if they had no impact on our qualitative conclusions. But they do: it would have been considerably more difficult, and in some cases impossible, to preserve the Greenland-Spitzbergen Bowhead stock while simultaneously maximizing profits if we move away from the ideal policy environment implicit in the standard theoretical model. More specifically, if we allow the regulator to make policy adjustments over time, if we limit the regulator's information set, if we reintroduce international competition, or if we reintroduce an employment motive into the regulator's objective function, then, as in the open-access environment, we again find stock depletion, eventual extinction, and in some cases profit dissipation.

\section{Allowing Policy Updates}

In fisheries models the social planner chooses a single, time invariant policy designed to maximize the present value of profits over the entire period of exploitation. This policy approach not only seems improbable in the dynamic economic, political, and social environment of eighteenthand nineteenth-century Netherlands, consideration of the time series pattern in aggregate industry profits derived from our optimal taxation simulation also suggests that the imposition of one policy, chosen in 1719 , is "time inconsistent." 59

In an effort to investigate the implications of policy updates we have performed two simulations in which the only change we make from the optimal revenue tax regime is to allow the regulator the opportunity to review the regulations at ten-year intervals.

In the first simulation the regulator can maintain the 46 percent revenue tax, or remove the tax. The present value of profits from the Dutch industry are increased if the regulator removes the tax as early as 1759 . The desire to very quickly return to open access is motivated by the very low, and in many years negative, profits that the Dutch industry would have suffered after 1865 . The economic misfortune of the Dutch industry at the end of the nineteenth century stems from dramatic changes in production methods and in the consumer market for whale products, in conjunction with rising real wages and the subsequent substitution away from Bowhead whale oil. ${ }^{60}$ With the tax removed after

\footnotetext{
${ }^{59}$ Throughout this section of the article we discuss only revenue taxation, rather than effort caps. With policy updates, these two methods of effort constraint are identical in terms of profits, effort, or stock levels. This policy irrelevance is consistent with theoretical results reported in Buchanan and Tullock, "Polluters' Profits"; Weitzman, "Prices Versus Quantities"; Copeland, "Taxes Versus Standards"; and Howe, "Taxes Versus Tradable Discharge Permits."

${ }^{60}$ Allen, "Great Divergence," tables 4, 5, 6.
} 
only 40 years the present value of the profits earned between 1719 and 1891 increase by 6.4 percent. However, as a consequence of the removal of the tax, stock depletion returns, with the average rate of decline in the Greenland-Spitzbergen Bowhead population equalling -1.75 percent per year. Under this scenario the stock falls below 1,500 individuals for the first time in 1891, 132 years after the removal of the tax.

In our second "policy adjustment" simulation, we provide the regulator with even more options by allowing policy updates at ten-year intervals that may include any tax rate between 99.9 percent and -99.9 percent. In this scenario the regulator can increase profits by repeatedly adjusting tax rates to exploit the exogenous volatility built into the model. Profits can be raised by 9.9 percent by varying tax rates between 16 percent and 59 percent. With the added flexibility, biological sustainability is again lost, as the stock declines at an average rate of -0.27 percent per year and only slightly more than 16,500 whales remain in the eastern Arctic stock in 1914. If we run this simulation beyond 1914 we predict stock extinction in 2008.

\section{Eliminating the Regulator's Perfect Foresight}

In fisheries models the social planner chooses a policy tool designed to maximize the present value of profits earned over the entire period of exploitation, 1719-1914. Implicit in this assumption is the notion that the social planner has perfect information about the evolution of all pertinent economic and biological variables over all 195 years. It is clear that even today, with our advanced state of ecological knowledge and our ability to forecast economic phenomena, regulators have a poor record when it comes to predicting future changes in prices, effort, and marine resource stocks. In our historic context it seems unreasonable to suggest that the hypothetical Dutch regulator could have had more information than regulators have today.

To limit the regulator's foresight we have performed a simulation in which we allow the regulator to update the revenue tax every ten years, but their objective is to maximize the present value of profits over only the subsequent decade, rather than the entire 1719-1914 period. In other words, we allow the regulator to maintain perfect foresight, but only over a ten-year period. ${ }^{61}$

\footnotetext{
${ }^{61}$ We have repeated this simulation using anticipated profits, where the regulator uses information on past profit to predict future profit. The results are slightly more volatile, but essentially unchanged from those reported in Table 4.
} 
TABLE 4

DEVIATIONS FROM THE OPTIMAL MANAGEMENT PROGRAM

\begin{tabular}{lccrrr}
\hline \hline \multicolumn{1}{c}{ Simulation Title } & Coverage & $\begin{array}{c}\text { Policy } \\
\text { (percentages) }\end{array}$ & Stock 1914 & $\begin{array}{c}\text { Year } \\
p \leq 1,500\end{array}$ & $\begin{array}{c}\text { PV Profits } \\
\text { (guilders) }\end{array}$ \\
\hline Tax removal in 1759 & $1719-1891$ & $t=46$ or $t=0$ & 0 & 1891 & $2,533,343$ \\
Ten-year updates & $1719-1914$ & $16 \leq t \leq 59$ & 16,579 & 2008 & $2,617,383$ \\
Shorten foresight & $1719-1914$ & $-55 \leq t \leq 99.9$ & 7,835 & 1988 & $3,280,135$ \\
Shorten foresight, $e \geq 108$ & $1719-1854$ & $5 \leq t \leq 52$ & 0 & 1854 & $-1,163,058$ \\
Shorten foresight, $e \geq 54$ & $1719-1914$ & $-46 \leq t \leq 91$ & 3,732 & 1937 & $2,948,141$ \\
\hline
\end{tabular}

Note: $p \leq 1,500$ identifies the year in which the whale population drops below 1,500. For explanation of simulation titles and policies see the text.

In the first decade, 1719-1729, the regulator chooses to shut the industry down, using a tax rate of 99.9 percent. In a later decade, 1739-1749, the regulator chooses to provide subsidies equal to 55 percent of the average revenue per ship. The other profit-maximizing tax rates cover a wide range of values between these two extremes. The adoption of very volatile tax rates is not unexpected, as the regulator would like to reduce effort in years in which marginal revenues were lower than marginal costs, and raise effort in years in which marginal revenues were higher than marginal costs. The end result is a substantial increase in profits, totalling over 3.28 million guilders in present value over the 1719-1914 period, but stock depletion at -0.66 percent per year, on average, with only 7,835 whales left in 1914, and predicted extinction in 1988.

With policy flexibility and perfect foresight over only the next ten years the regulator could have very effectively increased the profitability of the commercial industry, but the presence of persistent depletion suggests that the hunt would have been unsustainable in the long run (see Table 4).

\section{Reintroducing International Competition}

We have based our optimal management simulations on the "no British-no subsidies" Benchmark 2. This approach allowed us to focus on the impact various publicly provided institutional structures would have had on the economic efficiency of the Dutch commercial whaling industry and the biological sustainability of the eastern Arctic Bowhead without having to worry about any other government intervention, or British responses to Dutch regulation. However, the removal of international competition from the model effectively constrained our ability to identify the impact that strategic behaviour, increased and exogenous competitive pressure, and foreign demand fluctuations actually had on the Dutch industry and the whale population after 1719. 
The "no international competition" assumption is not totally unreasonable because some co-operation among captains may have been feasible. Certainly, the Dutch could have offered a share in as much as 3.28 million guilders as an incentive for co-operation; there is anecdotal evidence suggesting that informal, but binding season, location, and technique restrictions were observed by early pelagic whalers. ${ }^{62}$ However, there were no formal agreements promoting co-operation among whaling fleets from different nations, or even among vessels within each nation, and any informal agreements that may have existed were clearly not capable of saving the eastern Arctic Bowhead.

We have considered the impact British competition may have had on our simulation model in the presence of a profit-maximizing management program. There is a considerable body of literature that suggests that the most likely result of any effort restriction imposed on Dutch whalers in the presence of continued, unfettered foreign competition would have been the substitution of British effort for Dutch effort. ${ }^{63}$ Any reasonable assumptions we can make about British responses to unilateral Dutch effort restrictions imply that the Dutch regulator could not have had any substantive impact on the profitability of the Dutch industry, or the persistence of the Greenland-Spitzbergen Bowhead stock. Any reduction in Dutch effort would have simply been matched by a (lagged) increase in British effort. This suggests that unless the Dutch and British whaling captains had implemented effective cooperative strategies with respect to effort restrictions, or the Dutch had been able to extend national sovereignty to the eastern Arctic whaling grounds, an open-access environment would have prevailed, and therefore, both the Dutch commercial industry and the Bowhead would have been driven to extinction.

\section{Reintroducing an Employment Motive}

It is clear that, like most European and North American governments of today, the Dutch (and British) government intervened in its early commercial whaling industry with an employment, not profit, goal in

\footnotetext{
623.28 million guilders, representing approximately 1.9 years of total industry revenue, is the maximum present value of profits from any of our simulations reported in this article. de Jong, "Hunt of the Greenland Whales," p. 90, discusses the impact of co-operation among Dutch captains in Davis Strait. There is some evidence to suggest that until competition from the British became intense the Dutch refused to hunt young whales, pregnant females, or nursing mothers. Davis, Gallman, and Gleiter, In Pursuit, pp. 300-02, discuss the effects of collusion and competition on the productivity of U.S. whaling vessels during the nineteenth century.

${ }^{63}$ Levhari and Mirman, "Great Fish War"; Munro, "Optimal Management"; and Ruseski, "International Fish Wars."
} 
mind. Import duties on whale products and direct cost and revenue subsidies were offered to increase the size of the whaling fleet, and to encourage the use of native-born sailors. It was hoped that these well trained and experienced native-born sailors could then be pressed into the Dutch Navy during times of war. The standard theoretical assumption, therefore, that the sole objective of a Dutch regulator would have been profit maximization is not realistic.

To reintroduce an employment motive into our simulation model we have assumed that the regulator's objective is still the maximization of the present value of the profits earned off the exploitation of the Greenland-Spitzbergen Bowhead, but we have also imposed a minimum fleet size. This suggests that the regulator can now maximize profits, as long as the number of participating vessels does not fall below the floor we set. We have imposed two arbitrarily chosen effort floors to illustrate the impact that an employment motive has on the simulation model.

During the period prior to the diversification of effort into Davis Strait, 1661-1718, the Dutch whaling fleet never dropped below 108 vessels (except in times of war). If we allow the regulator to choose a new tax rate every ten years, starting in 1719, with the objective of maximizing the present value of profits from the industry while maintaining a fleet no smaller than 108 vessels, then the optimal tax rate would fall between 5 percent and 52 percent, the stock would drop below 1,500 whales in 1854, and the present value of profits from the industry would be less than -1.16 million guilders. The imposition of a historically relevant employment goal, therefore, results in both stock extinction and complete profit dissipation that closely resembles the effects of open access.

In an effort to investigate the effects of a more modest employment goal, we have performed a second simulation in which we allow the regulator to choose a new tax rate every ten years, starting in 1719 , with the objective of maximizing the present value of profits from the industry while maintaining a fleet no smaller than 54 vessels; half the size of the smallest fleet prior to regulation. With this considerably lower effort floor the optimal tax rate varies between 91 percent and a 46 percent subsidy, the present value of profits are just less than 2.95 million guilders, but stock depletion returns, at an average rate of -1.04 percent per year, and there are only 3,732 Bowhead remaining in the eastern Arctic in 1914. Extending our simulation beyond 1914 allows us to predict extinction under this scenario in 1937 . We must conclude, therefore, that the reintroduction of an employment motive lowers potential profits, and leads to fairly dramatic rates of stock depletion. 
Given these simulation results, we can now identify a third lesson learned from the extinction of the eastern Arctic Bowhead: in the absence of a policy environment that closely approximates that implied by standard fisheries models, we should not expect to find economic efficiency and biological sustainability concurrently, even under an optimal management program. We can be even more specific; if the Dutch regulator had access to multiple policy tools over the period of study, if the Dutch regulator had imperfect foresight, if the British could not have been excluded, or if we allow employment to be maintained as a policy goal, then the Greenland-Spitzbergen stock of Bowhead whales would have experienced stock depletion, and in many cases, the Dutch industry would have experienced profit dissipation.

\section{CONCLUSIONS}

Using the stock of Bowhead whales resident off the east coast of Greenland as a case study, and employing an empirical study of the long-run, historical data, we have been able to highlight the evolutionary response of the biological and economic variables that characterize commercial marine resource exploitation. In general, our study emphasizes the importance of these long-run responses that are often overlooked in resource management models.

We conclude by reiterating the three lessons we believe the extinction of the eastern Arctic Bowhead can teach us. First, it is overly optimistic to expect bio-economic equilibria, with positive stock and effort levels, to exist for open-access environmental assets, even in the era prior to the wide-spread introduction of steam power to the extraction of marine resources. Second, a regulatory regime that successfully excludes participants from extraction can halt the profit dissipation and stock depletion associated with the tragedy of the commons, as long as the policy environment closely approximates that characterized by the theoretical ideal. The third lesson learned is that in a more historically relevant policy environment it is not at all certain that the depletion, and eventual extinction, of marine resource stocks, and the dissipation of profits associated with the tragedy of the commons can be averted.

Unfortunately, the underlying theme is a pessimistic one; the absence of any effective institutions designed to constrain participation in the Bowhead whale hunt, despite the potential economic incentives for their imposition, implies that these institutions were difficult and costly to put in place. In addition, even if these institutions had been implemented, any reasonable assumptions about the economic and ecological environment in which regulators made decisions imply that even opti- 
mal management could not have indefinitely preserved the stock. As with many current resource stocks and extractive industries, the eastern Arctic Bowhead and early Dutch whalers were probably doomed by some combination of the introduction of new technology and inexpensive substitutes, the limited information available to regulators, the presence of foreign competition, and the desire to maintain a minimum fleet size.

\section{REFERENCES}

Allen, Robert C. "The Great Divergence: Wages and Prices in Europe From the Middle Ages to the First World War." Explorations in Economic History 38, no. 4 (2001): 411-47.

Allen, Robert C., and Ian Keay. "The First Great Whale Extinction: The End of the Bowhead Whale in the Eastern Arctic." Explorations in Economic History 38, no. 4 (2001): 448-77.

Amundsen, E. S., T. Bjorndal, and Jon Conrad. "Open Access Harvesting of the Northeast Atlantic Minke Whale." Environmental and Resource Economics 6, no. 2 (1995): 167-85.

Bockstoce, J. Whales, Ice and Men: The History of Whaling in the Western Arctic. Seattle: University of Washington Press, 1986.

Braham, Howard W. "The Bowhead Whale, Balaena Mysticetus." Marine Fisheries Review 46, no. 4 (1984): 545-53.

Buchanan, James M., and Gordon Tullock. "Polluters' Profits and Political Response: Direct Controls Versus Taxes." American Economic Review 65, no. 1 (1975): 139-47.

Carlos, Ann, and Frank Lewis. "Property Rights, Competition, and Depletion in the Eighteenth Century Canadian Fur Trade: The Role of the European Market." Canadian Journal of Economics 32, no. 3 (1999): 705-28.

Chapman, D. "Evaluation of Marine Mammal Population Models." In Dynamics of Large Mammal Populations, edited by C. W. Fowler and T .D. Smith, pp. 27796. Toronto: John Wiley, 1981.

Clark, C. W. "The Economics of Over Exploitation." Science 181, no. 4100 (1973): $630-34$.

"A Delayed-Recruitment Model of Population Dynamics, With an Application to Baleen Whale Populations." Journal of Mathematical Biology 3, no. 4 (1976): 381-91.

Clark, C. W., F. H. Clarke, and G. R. Munro. "The Optimal Exploitation of Renewable Resource Stocks: Problems of Irreversible Investment." Econometrica 47, no. 1 (1979): 25-47.

Clark, C. W., and R. Lamberson, R. "An Economic History of Pelagic Whaling." Marine Policy 6, no. 1 (1982): 103-20.

Conrad, Jon. "Bioeconomics and the Bowhead Whale." Journal of Political Economy 97, no. 4 (1989): 974-87.

Copeland, Brian. "Taxes Versus Standards to Control Pollution in Imperfectly Competitive Markets." University of British Columbia Discussion Paper 91-03, Vancouver, BC, 1999. 
Craig, Lee A., and Charles R. Knoeber. "Manager Shareholding, the Market for Managers, and the End-Period Problem: Evidence from the U.S. Whaling Industry." Journal of Law, Economics and Organization 8, no. 3 (1992): 607-27.

Dasgupta, P. S., and G. M. Heal. Economic Theory and Exhaustible Resources. Cambridge: Cambridge University Press, 1979.

Davis, Lance, Robert Gallman, and Karin Gleiter. In Pursuit of Leviathan. Chicago: University of Chicago Press, 1997.

de Jong, C. "The Hunt of the Greenland Whales: A Short History and Statistical Sources." In Report of the International Whaling Commission, Special Issue No. 5, edited by M. F. Tillman and G. P. Donovan, pp. 83-106. Cambridge: International Whaling Commission, 1983.

de Vries, Jan, and O. van der Oude. The First Modern Economy. New York: Cambridge University Press, 1997.

Gordon, H. S. "Economic Theory of a Common Property Resource: The Fishery." Journal of Political Economy 62, no. 1 (1954): 124-42.

Hacquebord, Louwrens. "Three Centuries of Whaling and Walrus Hunting in Svalbard and its Impact on the Arctic Ecosystem." Environment and History 7, no. 2 (2001): 169-85.

Hardin, Garret. "The Tragedy of the Commons." Science 162, no. 3859 (1968): 124348.

Hartwick, John M. "Intergenerational Equity and the Investing of Rents from Exhaustible Resources." American Economic Review 67, no. 5 (1977): 972-74.

Howe, C. W. "Taxes Versus Tradable Discharge Permits: A Review in the Light of the U.S. and European Experience." Environmental and Resource Economics 4, no. 1 (1994): 151-69.

Jackson, G. The British Whaling Trade. Hamden: Archon Books, 1978.

Jenkins, J. T. A History of the Whale Fisheries. Port Washington: Kennikat Press, 1921 (Reprinted 1971).

Levhari, D., and L. J. Mirman. "The Great Fish War: An Example Using a Dynamic Cournot-Nash Solution.” Bell Journal of Economics 11, no. 1 (1980): 322-44.

Mitchell, Edward. Initial Population Size of Bowhead Whale (Balaena Mysticetus) Stocks: Cumulative Catch Estimates. Scientific Committee of the International Whaling Commission, Number SC/29/Doc33, Cambridge, 1977.

Munro, Gordon R. "The Optimal Management of Transboundary Fisheries: Game Theoretic Considerations." Natural Resource Modeling 4, no. 4 (1990): 403-26.

Neher, Phillip. Natural Resource Economics. New York: Cambridge University Press, 1990.

Porter, R. C. "The New Approach to Wilderness Preservation Through Benefit-Cost Analysis." Journal of Environmental Economics and Management 9, no. 1 (1982): 59-80.

Proulx, J-P. Whaling in the North Atlantic from the Earliest Times to the Mid-19th Century. Ottawa: Parks Canada, 1986.

Ricard, S. Traite Generale du Commerce, Volume 1. Amsterdam: E. von Harrevelt and A. Soetens, 1781.

Ross, W. G. "The Annual Catch of Greenland (Bowhead) Whales in Waters North of Canada, 1719-1915: A Preliminary Compilation.” Arctic 32, no. 1 (1979): 91121.

Ruseski, Gorzad. "International Fish Wars: The Strategic Roles for Fleet Licensing and Effort Subsidies." Journal of Environmental Economics and Management 36, no. 1 (1998): 70-88. 
Scorsby, W. An Account of the Arctic Regions With a History and Description of the Northern Whale Fishery, Volume 2. Edinburgh: Archibald, Constable, 1820.

Scott, Anthony. Natural Resources: The Economics of Conservation. Toronto: McClelland and Stewart, 1973.

. "The I.T.Q. as a Property Right: Where It Came From, How It Works, and Where It is Going." In Taking Ownership, edited by Brian Crowley, pp. 31-98. Halifax: Atlantic Institute for Market Studies, 1996.

Schaefer, M. B. "Some Considerations of Population Dynamics and Economics in Relation to the Management of Marine Fisheries." Journal of the Fisheries Research Board of Canada 14 (1957): 669-81.

Smith, Vernon L. "On Models of Commercial Fishing." Journal of Political Economy 77, no. 2 (1969): 181-98.

Tietenberg, Tom. Environmental and Natural Resource Economics Fifth Edition. Toronto: Addison, Wesley, Longman, 2001.

Vibe, C. "Arctic Animals in Relation to Climatic Fluctuations." In The Danish Zoogeographical Investigations in Greenland, 1-27. Copenhagen: C.A. Reitzels Forlag, 1967.

Weitzman, M. L. "Prices Versus Quantities." Review of Economic Studies 41, no. 4 (1974): 477-91. 